\title{
Effect of tannic acid on urease and protease produced from Proteus mirabilis
}

\author{
Omar sinan sadiq Al-Zaidi luma abd Alhady Zwein * \\ Department of Biology / AL-Rasheed University collage \\ * Department of Biology / Collage of education for pure science /Ibn Al-Haithum University of Baghdad \\ E-mail: omar.sinan94@gmail.com, lumaabdalhadee@yahoo.com
}

\begin{abstract}
Back ground: P.mirabilis is a gram negative bacterium, motile with its peritrichous flagella .Widely distributed in environment, especially in contaminated water and soil, Many virulence factors like LPS, urease, protease, hemolysin and biofilm formation play an important roles in the pathogenicity of $P$. mirabilis. Urease is a Nickel containing enzyme causes elevation of urine pH after hydrolyzing urea to ammonia and $\mathrm{CO}_{2}$ forming stones that blocks the urinary track.

Aims: The effect of tannic acid on the production of urease and protease.

Material and methods: Twenty one isolates of Proteus were collected from different sources, Clinical and animal sources all isolates were cultured on MacConkey and blood agar and identification of $P$. mirabilis by, Vitek -2 compact system. Determine the effect of tannic acid on the production of urease and protease.

Results: Twenty one isolates of Proteus were identified depending on Vitek-2 compact system, after identification, it turns out that only 18 isolate were $P$. mirabilis. All isolates were $100 \%$ able to produce urease and $72.2 \%$ isolate were able to produce protease. The addition of tannic acid showed an inhibitory effect on urease and protease production.

Conclusion: The effect of tannic acid on urease and protease depending on concentration, type of strain, incubation period, number of isolates and truculence of isolate.
\end{abstract}

Keywords: Proteus mirabilis, Urease, protease, Tannic acid.

\section{Introduction}

The term "Proteus" was used for the first time by Hauser and its refers to the ability to changing in form, after isolating Proteus from the putrefied meet and depending on the liquefy of gelatin, Hauser classify Proteus bacteria to three species mirabilis, vulgaris and zenkeri (1). Proteus then classified according to biochemical test to five species mirabilis, vulgaris, penneri, hauseri and myxofaciens (2). The genetic analysis of $16 S$ rRNA proves that Proteus mirabilis belongs to the family of Gammaproteobacteria (3). P.mirabilis is a gram negative bacterium, chemotrophic organism gain its energy from fermentation and respiration, motile with its peritrichous flagella forming concentric zones on the solidified agar (3).Widely distributed in environment (4), especially in contaminated water and soil, also its part of human colon normal flora (5), as well as contaminated catheters (6). Many virulence factors like LPS, urease, protease, hemolysin and biofilm formation play an important roles in the pathogenicity of P. mirabilis (7). Urease is a Nickel containing enzyme causes elevation of urine $\mathrm{pH}$ after hydrolyzing urea to ammonia and $\mathrm{Co}_{2}$ forming stones that blocks the urinary track. Crystalline assembly is one of the main reasons that lead to the formation of stones which in turn contribute in the protection of bacteria from the effect of antibiotics (8). $P$. mirabilis produce protease enzyme with 50 - kilodalton $(\mathrm{kDa})$, protease cleaves immunoglobulin $\mathrm{A} 1, \mathrm{~A} 2$, and $\mathrm{G}$, the cleavage of $\operatorname{IgA1}, 2$ occurs outside the hinge region, while cleaving of $\operatorname{IgG}$ occurs in the hinge region (9). Many substances inhibit the production of urease and protease enzymes produced $P$. mirabilis, like Curcumin (10), NAC (8), Ammonium salts (11), and leaves of Coccinia grandis (12). This study aimed to detect the effect of tannic acid on urease and protease production by Proteus mirabilis.

\section{Materials and methods}

Isolation and identification of Proteus

Twenty one isolates of Proteus were collected from different sources. Clinical isolates were 7 from urine (U), 3 for both wound swabs (W) and Sputum (S) and 4 from hospital environment (H.en), while isolates of animal sources were 2 from cat rectum (CR) and one for both chicken feces (CF) and dog rectum (DR). All isolates were cultured on MacConkey and blood agar media provided by (Oxiod). Biochemical tests (Catalase, oxidase, Methyl red, indole, voges - proskauer and citrate utilization) were used for identification of P. mirabilis (2), Vitek -2 compact system was used to confirm ours identification. 


\section{Urease and Protease production test}

The ability of urease production by $P$. mirabilis was investigated as mentioned in (13), while for protease production, a bacterial suspension for each isolate with a concentration of $\left(1.5 \times 10^{8}\right)$ cell per $\mathrm{ml}$ was prepared by inoculation of bacterial colonies into the normal saline, then $200 \mu \mathrm{l}$ of the suspension were carried to the wells that already done by using $\left(8 \mathrm{~mm}\right.$ ) cork borer in the skim milk agar, the media was incubated at $37^{\circ} \mathrm{C}$ for 24 hours and the diameter of hydrolysis zones were calculated (14).modified.

\section{Tannic acid effect on urease}

To determine the effect of tannic acid(BDH/England) on the production of urease enzyme in P. mirabilis, three concentrations $(0.001,0.01$ and 0.1$) \%$ of tannic acid were added urea agar and the isolates of $P$. mirabilis were cultured by streaking the slant of urea agar, and then the media aerobically at $37^{\circ} \mathrm{C}$ for 24 hours were incubated.

\section{Tannic acid effect on protease}

Three concentrations $(0.001,0.01$ and 0.1$) \%$ of tannic acid were mixed with skim milk agar before autoclaving and then $200 \mu \mathrm{l}$ of each bacterial suspension was carried to the bores that already done by using $(8 \mathrm{~mm})$ cork borer in the skim milk agar, the media was incubated at $37^{\circ} \mathrm{c}$ for 24 hours and the diameter of hydrolysis zones were calculated.

\section{Results and Discussion}

Morphology diagnosis was done by using macConkey and blood agar media showed that all isolates belong to genus Proteus (5). Biochemical tests indicate that only 18 isolates were P. mirabilis. All the bacterial isolates were giving a positive result for catalase and methyl red, while indol, oxidase and vogues -proskaur were negative and citrate utilization was variable (2). Vitek -2 compact system confirmed the diagnosis with percentage of 93-99\%.

\section{Urease and protease production}

The results of urease production revealed that all P. mirabilis isolates the clinical ones and animal sources isolates were urease positive as shown in Table (1).

Table (1): Urease production by $P$. mirabilis isolates

\begin{tabular}{ccc}
\hline $\begin{array}{c}\text { Bacterial } \\
\text { isolates(source) }\end{array}$ & $\begin{array}{c}\text { Urease } \\
\text { production(number } \\
\text { positive) }\end{array}$ & Percentage \\
\hline U & + & \\
W & + & \\
S & + & $100 \%$ \\
CF & + & \\
DR & + & \\
CR & + & \\
H.en & + & \\
\hline
\end{tabular}

\section{U: Urine, W: Wounds, S: Sputum, CF: chicken feces, DR: Dog rectum, CR: Cat rectum}

Our results consistent with (15)(16)(17)(18)(19)(20),whom indicate that the rate of urease production was (100\%) from P.mirabilis bacteria isolated from urine and wound swabs.

Concerning protease, as shown in Table (2), 13/18 (72.2\%) isolates were able to produce protease enzyme, the proportion of isolates producing the enzyme was distributed as follows: $5 / 7$ from urine , 2/2 for both wound swaps and sputum, 1/1 from dog rectum, 1/2 from cat rectum and 2/3 from hospital environment, while the isolate from chicken feces was unable to produce the enzyme. 
Table (2): Protease production by $P$. mirabilis isolates

\begin{tabular}{cccc}
\hline $\begin{array}{c}\text { Bacterial } \\
\text { isolates(source) }\end{array}$ & $\begin{array}{c}\text { Number of bacterial } \\
\text { isolates(total) }\end{array}$ & $\begin{array}{c}\text { Number of isolates } \\
\text { produced } \\
\text { protease(positive) }\end{array}$ & Percentage (\%) \\
\hline U & 7 & 5 & 72.2 \\
W & 2 & 2 & 100 \\
S & 2 & 2 & 100 \\
CF & 1 & 0 & 0 \\
DR & 1 & 1 & 100 \\
CR & 2 & 1 & 50 \\
H.en & 3 & 2 & 66.6 \\
\hline
\end{tabular}

U: Urine, W: Wounds, S: Sputum, CF: chicken feces, DR: Dog rectum, CR: Cat rectum

The results of current study showed that the rate of protease production is differ from one isolate to another depending on number and source of isolates, as noted P. mirabilis isolated from clinical samples are not very different from isolates of animal sources in their ability to produce protease and this may depends on the strain. AlDawah (20) pointed that the rate of urease production from P. mirabilis isolated from urine was (40\%), while Ali and Jasim (21) pointed out that (100\%) of P. mirabilis urine isolates were able to produce the enzyme. Al-Azawy (18) indicates that $P$. mirabilis isolated from wounds unable to produce protease, while Hussain (22) found that (100\%) of urine, cat rectum, wounds and dog rectum isolates were able to produce the enzyme and (90\%) of chicken feces isolates were able to produce protease. The variance between isolates may be due to the different in number of isolates, type of strain, source of isolate and the truculence of bacteria.

\section{Tannic acid effect on Urease}

Tannic acid effect was used to inhibit the production of urease; Table (3) shows the ability of P. mirabilis isolates to produce urease and the effect of tannic acid in urease production. The results showed that the effect of tannic acid is vary depending on source of isolate and concentration, as noted the concentration $(0.001 \%)$ unable to inhibit urease production in all isolates after 5 and 24 hours of incubation except sputum (S) isolate, after 5 hours of incubation the concentration $(0.01 \%)$ was unable to inhibit urease in clinical and animal isolate, but after completion of incubation for 24 hours no result has appear for wounds, sputum and chicken feces isolates, while in urine and dog rectum isolates tannic acid gives a low inhibition, as for $(0.1 \%)$ concentration, it was successful to inhibit urease production in both clinical and animal sources isolates.

Table (3): Tannic acid effect on urease production by $P$. mirabilis isolates

\begin{tabular}{|c|c|c|c|c|c|c|c|c|}
\hline \multirow[b]{2}{*}{$\begin{array}{c}\text { Bacterial } \\
\text { isolates }\end{array}$} & \multirow[b]{2}{*}{ Control 5h } & \multirow[b]{2}{*}{$\begin{array}{c}\text { Control } \\
24 \mathrm{~h}\end{array}$} & \multicolumn{6}{|c|}{ Concentration (\%) } \\
\hline & & & $\begin{array}{c}0.001 \\
5 \mathrm{~h}\end{array}$ & $\begin{array}{c}0.001 \\
24 h\end{array}$ & $\begin{array}{c}0.01 \\
5 \mathrm{~h}\end{array}$ & $\begin{array}{c}0.01 \\
24 h\end{array}$ & $\begin{array}{c}0.1 \\
5 h\end{array}$ & $\begin{array}{c}0.1 \\
24 h\end{array}$ \\
\hline $\mathbf{U}$ & \pm & + & \pm & + & \pm & - & - & - \\
\hline W & \pm & + & \pm & + & \pm & - & - & - \\
\hline $\mathbf{S}$ & \pm & + & \pm & \pm & \pm & - & - & - \\
\hline $\mathbf{C F}$ & \pm & + & \pm & + & \pm & - & - & - \\
\hline DR & \pm & + & \pm & + & \pm & - & - & - \\
\hline CR & \pm & + & \pm & + & \pm & - & - & - \\
\hline
\end{tabular}

U: Urine, W: Wounds, S: Sputum, CF: chicken feces, DR: Dog rectum,CR: Cat rectum, h:Hours, $\pm(50 \%$ positive $+50 \%$ negative $)+: 100 \%$ positive,$-: 100 \%$ negative

Tannic acid gives a clear effect to inhibit urease activity and this may be due the binding with active site of the enzyme causing changing in the structure of the enzyme, or the acid effect may inhibit quorum sensing systems (QS) leading to inhibition of virulence factors including urease enzyme, and in the same time tannic acid caused an inhibitory effect on swimming and swarming motility of $P$. mirabilis which composition is synchronized with virulence factors. Also the inhibitory effect of tannic acid may be attributed to its effect on many genes like $R s b \mathrm{~A}$ 
that related to swarming phenomenon and virulence factors (23), while Ranjbar-Omid (24) point out that some substances have the ability to inhibit proton pump (proton pump inhibitors) that inhibit urease production.

\section{Tannic acid effect on Protease}

The inhibitory efficacy of tannic acid on protease production was estimated as shown in figure (1), both concentrations $(0.01$, and 0.1$) \%$ were able to inhibit protease production in both clinical and animal sources isolates, while the concentration $(0.001 \%)$ was able to inhibit protease production in all isolates except wound swaps (W) and dog rectum (DR) isolates. Tannic acid show an inhibitory effect even in low concentration, and the inhibition of enzyme may be due to the same reasons of urease enzyme inhibition, tannic acid bind with active site of protease enzyme which leads to changing in the structure of enzyme causing its inhibition. Or the inhibitory effect may be on chemical signals (QS) which lead to inhibit the virulence factors including protease. In the same time tannic acid may effect on swimming and swarming motility of $P$. mirabilis bacteria and its virulence factors or it may effect on some genes like RsbA (23).

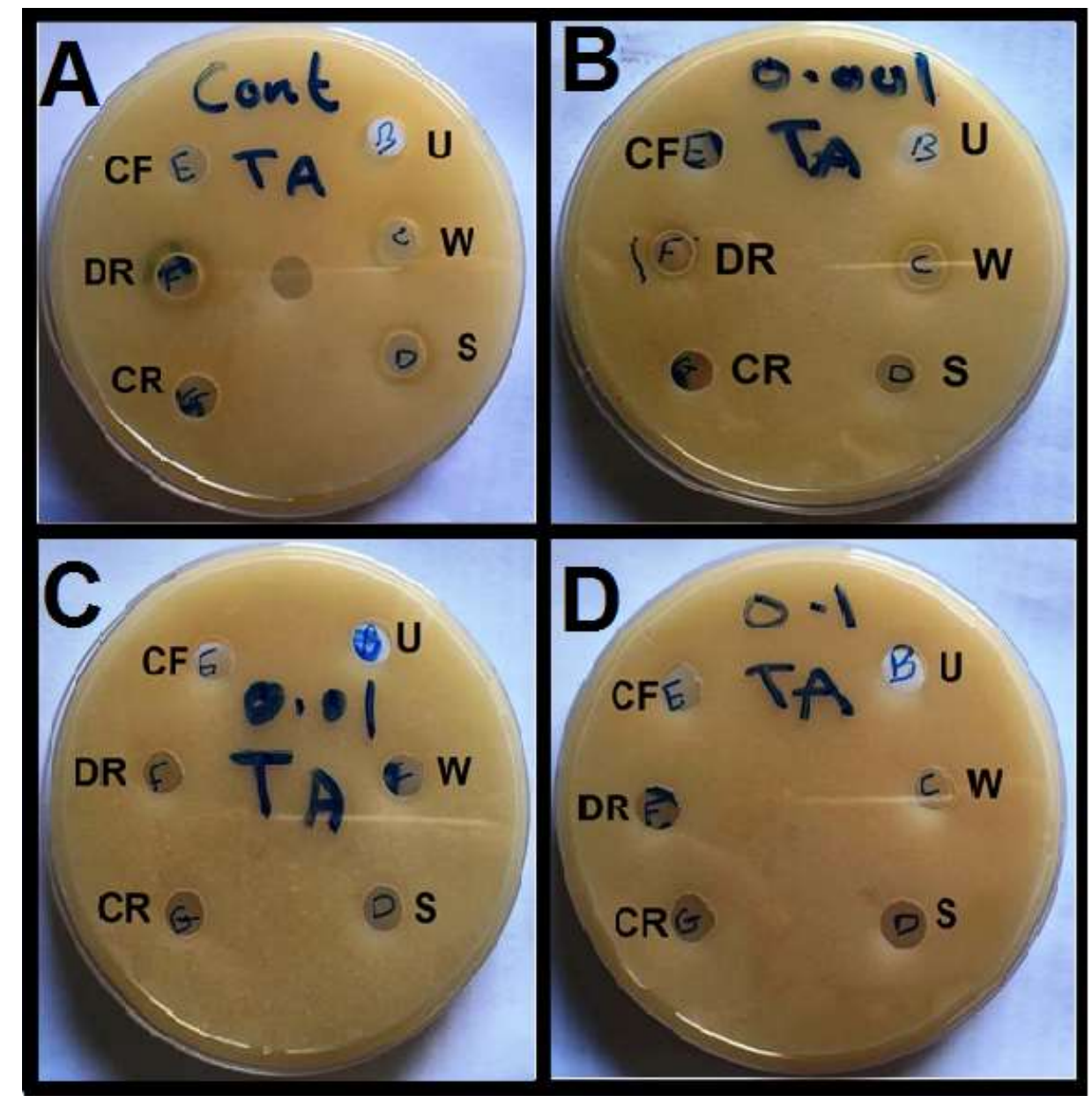

Figure (1): Effect of tannic acid on protease production in $P$. mirabilis isolates

A: Milk agar (control), B: Milk agar+0.001\% tannic acid, C: Milk agar+0.01\% tannic acid, D: Milk agar+0.01\%tannic acid

\section{References}

1. Wenner JJ, Rettger LF. A systematic study of the Proteus group of bacteria. J. of Bacteriology. (1919); 4:331-353.

2. O'hara CM, Brenner FW, Miller JM. Classification, identification, and clinical significance of Proteus, Providencia, and Morganella. Clinical Microbiology Reviews. (2000); 13(4):534-546. 
3. Garrity GM, Brenner DJ, Krieg NR, Staley JT, Chairman Boone DR, Chairman V, De Vos P, Goodfellow M, Rainey FA, Schleifer KH. Bergey's manual of systematic bacteriology, Vol. 2 the proteobacteria Part B the Gammaproteobacteria. Publisher Springer. (2005); 304.

4. Kwill I, Kazmierczak D, Rozalski A. Swarming Growth and Resistance of Proteus penneri and Proteus vulgaris Strains to Normal Human Serum. Advances in Clinical and Experimental Medicine. (2013); 22(2):165-175.

5. Levinson W. Review of medical microbiology and immunology. $14^{\text {th }}$ ed. McGraw-Hill education, Inc. (2016); 821.

6. Mohammed GJ, Kadhim MJ, Hameed, IH. Proteus species: characterization and herbal antibacterial: a review. International J. of Pharmacognosy and Phytochemical Research. (2016); 8(11): 1844-1854.

7. Rozalski A, Torzewska A, Moryl M, Kwil I, Maszewska A, Ostrowska K, Drzewiecka D, Zablotni A, Palusiak A, Siwinska M, Staczek P. Proteus sp.- an opportunistic bacterial pathogen-classification, swarming growth, clinical significance and virulence factors. Folia Biologica et Oecologica. (2012); 8:1-17.

8. Abdel-Baky RM, Ali MA, Abuo-Rahma G, ED, AA, AbdelAziz N. Inhibition of urease enzyme production and some other virulence factors expression in Proteus mirabilis by N-Acetyl Cysteine and Dipropyl Disulphide. In: G. Donelli (eds) Advances in microbiology, infectious diseases and public health. Advances in experimental medicine and biology. Springer, Cham. (2017); 973: 99-113.

9. Loomes LM, Senior BW,Kerr MA. A proteolytic enzyme secreted by Proteus mirabilis degrades immunoglobulins of the immunoglobulin $\mathrm{Al}$ ( $\mathrm{IgAl}), \operatorname{IgA} 2$, and $\operatorname{IgG}$ isotypes. Infection and Immunity. (1990); 58(6): 1979-1985.

10. Prywer J, Torzewska A. Effect of curcumin against Proteus mirabilis during crystallization of struvite from artificial urine. Hindawi Publishing Corporation. (2012): 1-7.

11. Liu PV, Hsieh H-C. Inhibition of protease production of various bacteria by ammonium salts: its effect toxin on production and virulence. J. of Bacteriology. (1969); 99(2): 406-413.

12. Satheesh LS, Murugan K. Antimicrobial activity of protease inhibitors from leaves of Coccinia grandis (1.)voigt. . Indian J. of Experimental Biology. (2010); 49: 366-374.

13. Tille PM. Baily and Scott's Diagnostic Microbiology.12th ed., Mosby, Inc., an anffilliate of Elsevier, Inc, (2010); 1038.

14. Senior BW. Investigation of the types and characteristics of the proteolytic enzymes formed by diverse strains Proteus of species. J. of Medical Microbiology. (1999); 48(7): 623-628.

15. Kafaf PM. Study on some biological activity and biotyping of Proteus mirabilis isolated from clinical samples. M.Sc. Thesis. Al-Mustansiryia University College of Science. (2006); 178.

16. Al-Bassam WW, Al-Kazaz A-K. The Isolation and characterization of Proteus mirabilis from different clinical samples. J. of Biotechnology Research Center. (2013); 7(2): 24-30.

17. Ali TH, Jasim HM. Detection of virulence factors of local isolates of Proteus mirabilis. J. of Al-Nahrain University - Science. (2014); 17(4): 137-143.

18. Al-Azawy AN, Al-Taai HRR, Al-Rajab IAM. Biological study of Proteus mirabilis isolated from different clinical sources in Al- Mqdadia city. Diyala J. for pure science. (2014); 11(2):42-60.

19. Ahmed DA. Prevalence of Proteus spp. in some hospitals in Baghdad city. Iraqi J. of Science. 2015; 65(1): 665-672.

20. Al-Dawah MJ; Al-Hamadany AH, Al-Jarallah EM. Study of some virulence factors of Proteus mirabilis isolated from urinary stones patients. J. of Biology, Agriculture and Healthcare. (2015); 5(23): 85-95.

21. Ali TH, Jasim HM. Detection of virulence factors of local isolates of Proteus mirabilis. J. of Al-Nahrain University - Science. (2014); 17(4): 137-143.

22. Hussain ASK. Bacteriological and molecular study of Proteus mirabilis isolated from clinical and animal sources. MSc. thesis. Collage of education for pure science/ ibn-alhaithum. University of Baghdad. (2016); 123.

23. Liaw SJ, Lai HC, Wang WB. Modulation of swarming and virulence by fatty acids trough the $R s b$ A protein in Proteus mirabilis. Infection and Immunity. (2004); 72: 6836-6845.

24. Ranjbar-Omid M, Arzanlou M, Amani M, Shokri Al-Hashem SK, Mozafari A, Doghaheh HP. Allicin from garlic inhibits the biofilm formation and urease activity of Proteus mirabilis in vitro. Federation of European Microbiological Societies. (2015); 363(9): 1-9. 